\title{
Comparison Between Conventional Design and Cathode Gas Recirculation Design of a Direct-Syngas Solid Oxide Fuel Cell- Gas Turbine Hybrid Systems Part II: Effect of Temperature Difference at The Fuel Cell Stack
}

\author{
Vahid Azami a and Mortaza Yari b,* \\ a Department of Mechanical Engineering, University of Mohaghegh Ardabili, Ardabil, Iran \\ ${ }^{b}$ Department of Mechanical Engineering, University of Tabriz, Tabriz, Iran
}

\begin{abstract}
This study focuses on the effect of the temperature difference at the fuel cell stack $\left(\Delta \mathrm{T}_{\text {cell }}\right)$ on the performances of the two types of SOFC-GT hybrid system configurations, with and without cathode gas recirculation system. In order to investigation the effect of matching between the SOFC temperature $\left(\mathrm{T}_{\mathrm{SOFC}}\right)$ and the turbine inlet temperature (TIT) on the hybrid system performance, we considered additional fuel supply to the combustor as well as cathode gas recirculation system after the air preheater. Simulation results show that the system with cathode gas recirculation gives better efficiency and power capacity for all design conditions than the system without cathode gas recirculation under the same constraints. As the temperature difference at the cell becomes smaller, the both systems performance generally degrade. However, the system with cathode gas recirculation is less influenced by the constraint of the cell temperature difference. The model and simulation of the proposed SOFC-GT hybrid systems have been performed with CycleTempo software.
\end{abstract}

Keywords: Solid oxide fuel cell, Gas turbine, Cathode gas recirculation, Exergy.

Article History: Received January $16^{\text {th }} 2018$; Received in revised form July $4^{\text {th }} 2018$; Accepted October $5^{\text {th }} 2018$; Available online How to Cite This Article: Azami, V and Yari, M. (2018) Comparison Between Conventional Design and Cathode Gas Recirculation Design of a Direct-Syngas Solid Oxide Fuel Cell-Gas Turbine Hybrid Systems Part II: Effect of Temperature Difference at The Fuel Cell Stack. International Journal of Renewable Energy Development, 7(3), 263-267.

http://dx.doi.org/10.14710/ijred.7.3.263-267

\section{Introduction}

Climate change, security of supply and decrease in fossil fuels has stimulated the need to develop power generation technologies that are environmentally friendly and highly efficient to replace a conventional combustion-based power system.

A solid oxide fuel cell-gas turbine hybrid system (SOFC-GT system) has been received much attention for a distributed power generation due to its high efficiency and flexibility for different fuels. In comparison with other alternative fuel, syngas obtained from biomass gasification is a very attractive green fuel for use in solid oxide fuel cells. It has relatively high hydrogen content and can be produced renewably through the gasification process of biomass feedstocks and thus, a promising alternative fuel for the SOFC-GT hybrid system.

In spite of the introduction of many innovative cycles for the SOFC-GT hybrid system, its universal configuration is not yet fully established. Studies to develop new system configurations for better performance are still in progress. When considering a performance of the system, it is found that a heat input is highly required to preheat air before being fed to the SOFC stack. The recirculation of a high temperature cathode exhaust gas is probably an interesting option to reduce the requirement of an external heat for the SOFC-GT system (Saebea et al. 2012; Saebea et al. 2013).

In the first part of this presentation, it was shown that the cathode gas recirculation, has a major impact on the on both the SOFC and gas turbine performances (Azami et al. 2017). In the analysis, first the conventional SOFC-GT hybrid system (CS) was presented. In this reference case, the net energy and exergy efficiencies of the hybrid cycle were $54.53 \%$ and $55.8 \%$, respectively. The corresponding efficiencies for the SOFC-GT hybrid system with cathode gas recirculation system (CRS) were $64.76 \%$ and $66.28 \%$, respectively. AC energy efficiencies for the SOFC and GT generator in the system without cathode recirculation were $50.83 \%$ and $35.98 \%$, respectively. Also, AC energy efficiencies for the SOFC

*Corresponding author: myari@tabrizu.ac.ir 
Citation: Azami, V and Yari, M. (2018) Comparison Between Conventional Design and Cathode Gas Recirculation Design of a Direct-Syngas Solid Oxide Fuel Cell-Gas Turbine Hybrid Systems Part II: Effect of Temperature Difference at The Fuel Cell Stack. Int. Journal of Renewable Energy Development, 7(3),263-267, doi.org/10.14710/ijred.7.2.263-267

P a g e | 264

and GT in the system with cathode recirculation were $50.67 \%$ and $37.99 \%$, respectively (Azami et al. 2017).

The SOFC-GT hybrid system with anode and cathode exhaust gas recycling is an interesting power system that can minimize the required heat input for the system and maximize the system efficiency. However, effect of the temperature difference at the fuel cell stack is not considered for SOFC-GT hybrid system with cathode gas recirculation and a study is required to investigate on the performance such systems.

In Part I, comparison between design performances of the two types of SOFC-GT hybrid system configurations, with and without cathode gas recirculation system were investigated. In this paper, in order to better understand the behaviors of the systems, the effects of the temperature difference at the fuel cell stack on the performance of the cycle were investigated. The proposed SOFC-GT hybrid systems (with and without cathode gas recirculation system) have been carried out using CycleTempo software (Cycle-Tempo software 2017), which was developed by Delft University of Technology as a modern tool for the thermodynamic analysis and optimization of systems for the production of electricity, heat and refrigeration.

\section{Hybrid system modeling process}

In Part I of this presentation, Figs. 1 and 3 were used to explain the operation of the hybrid SOFC-GT cycle fuelled with sungas when it was operated in both configurations (Azami et al. 2017). The major differences between two cycles are the option which employed for heating cathode inlet stream. In CRS the cathode inlet air after heated at the air recuperating and air preheating components is mixed with depleted air from the cathode air recycle before entering the SOFC, while in the CS the incoming air to the cathode is heated at the air recuperator and air preheater to meet the required cathode inlet temperature.

\section{Hybrid system modeling process}

They are two options to determine the power level of the system. One option is to specify the fuel mass flow, the other option is to set the power output load of the SOFC or GT unit. In the present work, the power level given for the GT determine the mass flow through the GT and hence through the system. The energy balance at the fuel cell determines the cathode air flow based on the cooling air required. These two units, namely the fuel cell unit and the gas turbine unit together play an important role in determining the inlet fuel flow. Since this study intends to perform a design analysis, the current density of the unit cell is assumed to be constant for all temperature difference at the cell. Therefore, different powers obtained from the analysis can be realized by different cell stack size (e.g., number of stacked cells).

The SOFC is a direct internal reforming fuel cell operating at $950 \circ \mathrm{C}$ on average. This SOFC type is anode supported and the anode consists of Nickel/Gadolinia Doped Ceria (Ni/GDC) and the cathode of Lanthanum Strontium Manganite (LSM) cathodes (Aravind et al. 2009). The Brayton cycle has been also modeled with the aid of Cycle-Tempo software (Cycle-Tempo software 2017). The basic structure of a recuperator gas turbine consisting of an air compressor, recuperator, combustion chamber and expansion turbine. Cycle-Tempo employs a Gibbs free energy minimization based routine for equilibrium calculations in the combustor model and in the fuel cell model used in these calculations. Details of these models are available in the Cycle-Tempo manual (Cycle-tempo manuals 2017) and in other similar works such as Aravind et al. (2009), Toonssen et al. (2010), Fernandes et al. (2015), Santhanam et al (2016), Thallam Thattai et al. (2017).

The ejector is an important component as it (1) compensates pressure losses in the anode chamber of the fuel cell stack, (2) recirculates the anode-off gas which is steam rich and supplies sufficient steam to support the reforming taking place in external reformer (Ming et al. 2011), and (3) providing anode inlet temperature of fuel cell. In the anode recycle, a blower is used to simulate the functions of the ejector in the fuel cell and in the cathode recycle, a blower is used to overcome the pressure drop in the fuel cell.

\section{Results and Discussion}

Fig. 1 show the effect of $\Delta \mathrm{T}_{\text {cell }}$ on air mass flow rate to the cathode of the CRS and air input to the both CS and CRS. When $\Delta \mathrm{T}_{\text {cell }}$ is increased from 50 to $150 \circ \mathrm{C}$ and since the pressure ratio and turbine inlet temperature are fixed, the air the mass flow to the both systems is decreased because higher $\Delta \mathrm{T}_{\text {cell }}$ means that lower cooling air required to keep the SOFC at the required operating temperature. As Fig. 1 show, due to cathode recirculation the air mass flow rate to the system in the configuration with cathode recirculation is slightly lower than that in the conventional configuration at the all $\Delta \mathrm{T}_{\text {cell. }}$. While, comparison of the SOFC cathode inlet air mass flow in Fig. 1 shows that for all $\Delta \mathrm{T}_{\text {cell }}$ the cathode inlet air mass flow of the SOFC in the configuration with cathode recirculation is significantly higher than that in the configuration without cathode recirculation. The reason is when the fuel recuperator exhaust is partially bypassed to the combustor, in order to adjust the turbine, anode and cathode inlet temperature, before entering the SOFC, the mass flow rate of the anode inlet reduces in the cycle without cathode recirculation. This means lower cooling air required to keep the fuel cell at the required operating temperature in the conventional configuration.

On the other hand, lower cooling air causes higher fuel input to the system with increasing $\Delta \mathrm{T}_{\text {cell, }}$, because the mass flows through the system and hence the power level is set by the gas turbine generator fixed at $1000 \mathrm{~kW}$ and hence the total energy input to the both systems increase, as shown in Fig. 2. The comparison of energy input to the system for two configurations shows that the energy input to the system is higher in the configuration with cathode recirculation at the all $\Delta \mathrm{T}_{\text {cell. }}$. The reason is when the SOFC cathode exhaust is partially recycled before entering the combustor, the air mass flow rate of the combustor reduces in the cycle with cathode recirculation. As low air is entered to the combustor, and there is no variation in the turbine inlet temperature and pressure ratio and since the generator produces is fixed, the mass flow through the turbine decreases. This causes higher fuel input to the system and hence the higher energy input to the system, as shown in Fig. 2. The exergy input of both systems, shown in Fig. 3 has a similar changing trend as energy input. 


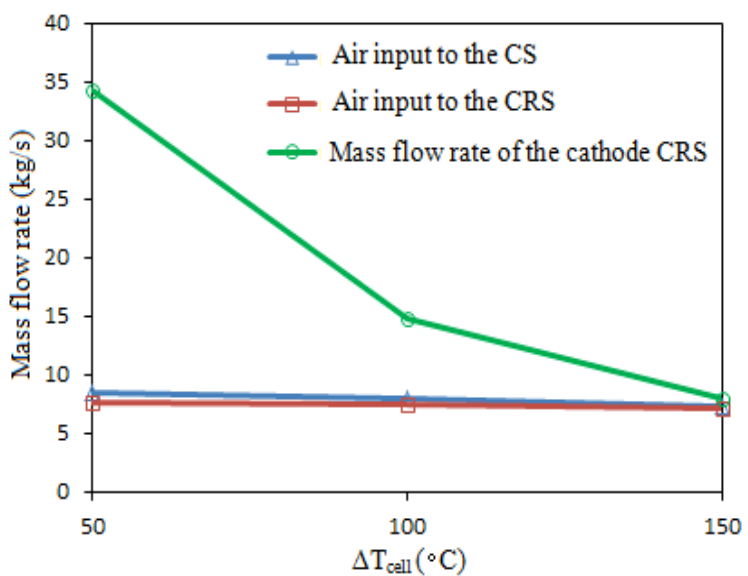

Fig. 1 Effects of $\Delta \mathrm{T}_{\text {cell }}$ on the air mass flow rate of the systems.

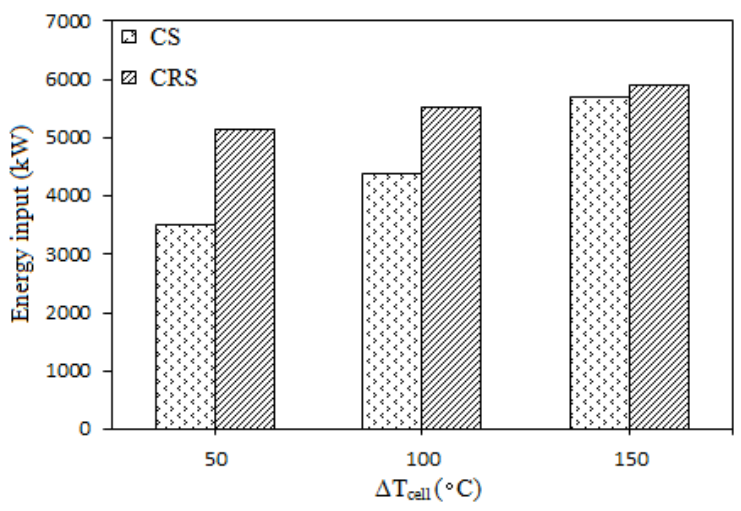

Fig. 2 Effects of $\Delta \mathrm{T}_{\text {cell }}$ on the energy input of the systems.

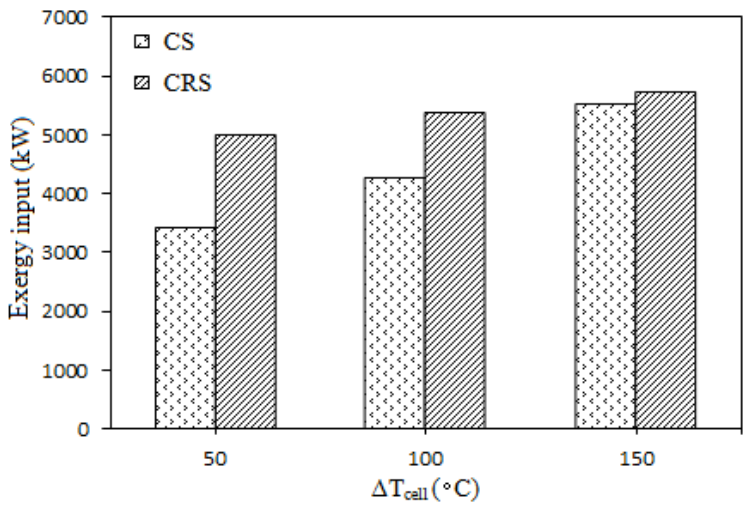

Fig. 3 Effects of $\Delta \mathrm{T}_{\text {cell }}$ on the exergy input of the systems.

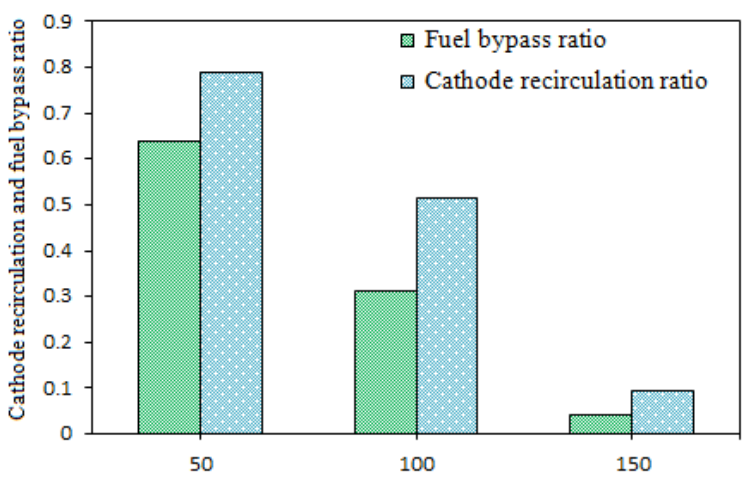

Fig. 4 Effects of $\Delta \mathrm{T}_{\text {cell }}$ on the fuel bypass and cathode recirculation ratio of the systems.

Fig. 4 reveals the effects of $\Delta \mathrm{T}_{\text {cell }}$ on the fuel bypass and cathode recirculation ratio of the systems. It can be seen that, due to decreasing anode and cathode inlet temperature both the fuel bypass ratio and cathode recirculation ratio decrease with the increasing $\Delta \mathrm{T}_{\text {cell. }}$.

Fig. 5 shows the effects of $\Delta \mathrm{T}_{\text {cell }}$ on the power of turbine and compressor of the both CS and CRS. As the $\Delta \mathrm{T}_{\text {cell }}$ increases, due to higher air mass flow rate to the system and hence higher mass flow through the turbine and compressor the gas turbine power output and the compressor power consumption increase. Compared with the CS, an increase in $\Delta \mathrm{T}_{\text {cell }}$ leads to little decrease in turbine power output and compressor power consumption of the CRS. As Fig. 5 show, due to higher air mass flow rate to the system and hence higher mass flow through the turbine and compressor and since the generator produces is fixed, air compressor power consumption and hence gas turbine power production in the conventional configuration is slightly higher than that in the configuration with cathode recirculation at the all $\Delta \mathrm{T}_{\text {cell. }}$.

Fig. 6 shows the effects of $\Delta \mathrm{T}_{\text {cell }}$ on the power of SOFC and GT components of the both systems. It can be seen that, increasing the $\Delta \mathrm{T}_{\text {cell }}$ from $50 \circ \mathbf{C}$ to $150 \circ \mathbf{C}$ increased the SOFC AC output power of the CS significantly, from about 607 to $2929 \mathrm{kw}$. This is because that the fuel bypassed rate decreased with the increasing $\Delta \mathrm{T}_{\text {cell }}$, resulting in an increase in the anode mass flow rate of the SOFC. In addition, increasing the $\Delta \mathrm{T}_{\text {cell }}$ from $50 \circ \mathbf{C}$ to $150 \circ \mathbf{C}$ increased the SOFC AC output power of the CRS, from about 2421 to $3159 \mathrm{kw}$ due to the relatively decrease in the air mass flow rate of the cathode side. Compared with the CS, an increase in $\Delta \mathrm{T}_{\text {cell }}$ leads to little increase in SOFC AC power output of the CRS. Comparison of the SOFC AC output power in Fig. 6 shows that the output power of the SOFC in the configuration without cathode recirculation is significantly lower than that in the configuration with cathode recirculation at the all $\Delta \mathrm{T}_{\text {cell. }}$. The reason is when the fuel recuperator exhaust is partially bypassed to the combustor before entering the fuel preheater, the fuel mass flow rate of the SOFC anode inlet reduces in the cycle without cathode recirculation. Therefore, there is less power generated in the SOFC of the conventional configuration.

Fig. 7 shows the effects of $\Delta \mathrm{T}_{\text {cell }}$ on the gross energy efficiency of the both systems. It can be seen that, increasing the $\Delta \mathrm{T}_{\text {cell }}$ from $50 \circ \mathbf{C}$ to $150 \circ \mathbf{C}$ increased the gross energy efficiency of the CS and CRS, from about 45.97 to $69.38 \%$ and 66.99 to $70.82 \%$, respectively due to the increasing AC power output of the SOFC. On the other hand, due to higher SOFC power output of the configuration with cathode recirculation and since the generator power produce of both cycle without and with cathode recirculation is equal to $1000 \mathrm{~kW}$, gross energy efficiency of the SOFC-GT hybrid system in the configuration with cathode recirculation is significantly higher than that in the configuration without cathode recirculation for all $\Delta \mathrm{T}_{\text {cell }}$ as shown in Fig. 7 .

The increasing $\mathrm{AC}$ power output of the SOFC is also the reason for the increasing the net energy efficiency of the CS and CRS with increasing the $\Delta \mathrm{T}_{\text {cell }}$ as shown in Fig. 8. It can be seen that, net energy efficiency for the CS and CRS increases from 42.47 to $65.8 \%$ and from 61.59 to $67.19 \%$, respectively, when $\Delta \mathrm{T}_{\text {cell }}$ is increased from $50 \circ \mathbf{C}$ to $150 \circ \mathbf{C}$. Compared with the $\mathrm{CS}$, an increase in $\Delta \mathrm{T}_{\text {cell }}$ leads to little increase in gross and net energy efficiency of the CRS (see Figs. 7 and 8 ). In addition, due to higher SOFC AC power output, the net energy efficiency of the hybrid system in the configuration with 
Citation: Azami, V and Yari, M. (2018) Comparison Between Conventional Design and Cathode Gas Recirculation Design of a Direct-Syngas Solid Oxide Fuel Cell-Gas Turbine Hybrid Systems Part II: Effect of Temperature Difference at The Fuel Cell Stack. Int. Journal of Renewable Energy Development, 7(3),263-267, doi.org/10.14710/ijred.7.2.263-267

$\mathrm{P}$ a g e | 266

cathode gas recirculation is significantly higher than that in the configuration without cathode gas recirculation at all $\Delta \mathrm{T}_{\text {cell }}$ (see Fig. 8).

The gross and net exergy efficiency of the system, shown in Figs. 9 and 10 has a similar changing trend as energy conversion efficiency. Gross exergy efficiency for the CS and CRS increases from 47.04 to $71 \%$ and from 68.55 to $72.47 \%$, respectively and net exergy efficiency from 43.46 to $67.34 \%$ and from 63.03 to $68.76 \%$, respectively when $\Delta \mathrm{T}_{\text {cell }}$ is increased from $50 \circ \mathbf{C}$ to 150 -C. Compared with the CS, an increase in $\Delta \mathrm{T}_{\text {cell }}$ leads to little increase in gross and net exergy efficiency of the CRS (see Figs. 9 and 10 ). In addition, due to higher gross and net output power, the gross and net exergy efficiency of the hybrid system in the configuration with cathode gas recirculation is significantly higher than that in the configuration without cathode gas recirculation at all $\Delta \mathrm{T}_{\text {cell }}$ (see Figs. 9 and 10 ).

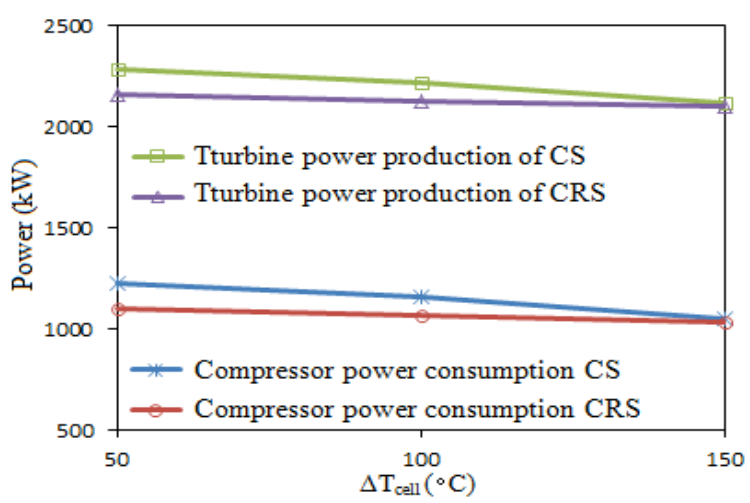

Fig. 5 Effects of $\Delta \mathrm{T}_{\text {cell }}$ on the turbine and compressor power of the systems.

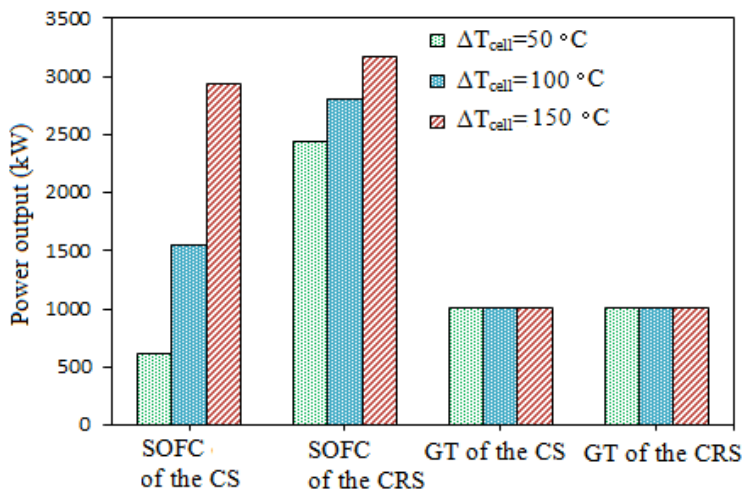

Fig. 6 Effects of $\Delta \mathrm{T}_{\text {cell }}$ on the SOFC and GT power of the systems.

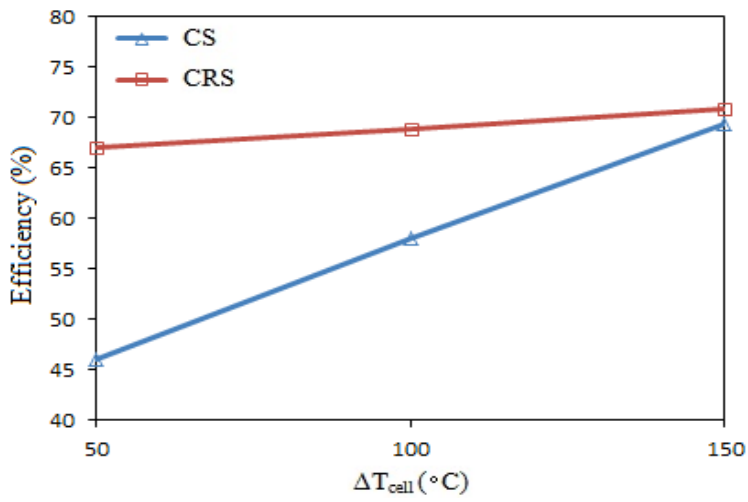

Fig. 7 Effects of $\Delta \mathrm{T}_{\text {cell }}$ on the gross energy efficiency of the systems.

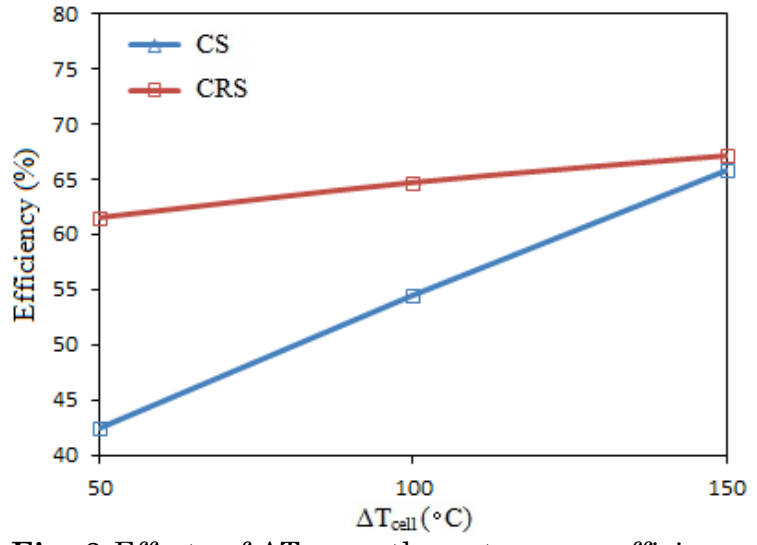

Fig. 8 Effects of $\Delta \mathrm{T}_{\text {cell }}$ on the net energy efficiency of the systems.

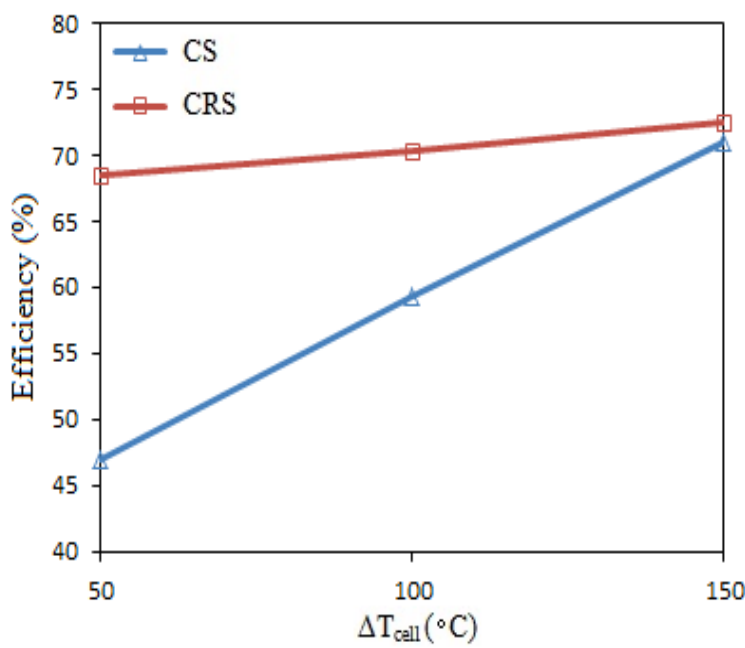

Fig. 9 Effects of $\Delta \mathrm{T}_{\text {cell }}$ on the gross exergy efficiency of the systems.

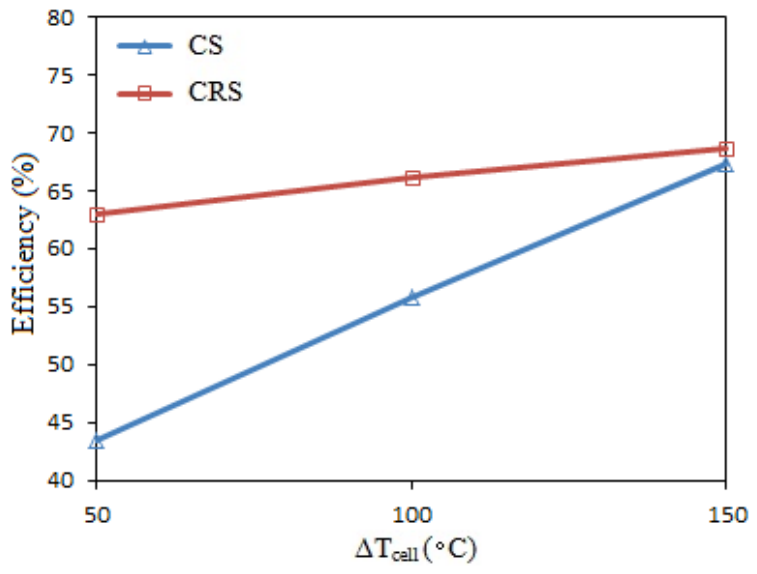

Fig. 10 Effects of $\Delta \mathrm{T}_{\text {cell }}$ on the net exergy efficiency of the systems.

\section{Conclusion}

In this paper the SOFC-GT hybrid system fuelled by syngas from biomass gasification was evaluated by thermodynamic calculations to study the influence of the temperature difference on the overall system performance. Two alternative options were proposed to provided, required heat for the heated fuel and air streams to the anode and cathode inlet temperature. The main conclusions are summarized as follows: 
- Increasing the $\Delta \mathrm{T}_{\text {cell }}$ could increase SOFC power output of both hybrid system, but compared with the $\mathrm{CS}$, an increase in $\Delta \mathrm{T}_{\text {cell }}$ leads to little increase in SOFC power output of the CRS. Although the generator power produce of both cycle with and without cathode recirculation were equal to 1000 $\mathrm{kW}$, the SOFC power output of the cycle with cathode recirculation was much higher than that in the cycle without cathode recirculation, which means higher efficiency for the same generator power produce for all $\Delta \mathrm{T}_{\text {cell }}$.

- Gross energy efficiency and net energy efficiency of the both system can be increase by increasing the $\Delta \mathrm{T}_{\text {cell }}$ under the given condition, but compared with the CS, an increase in $\Delta \mathrm{T}_{\text {cell }}$ leads to little increase in gross and net energy efficiency of the CRS. However, gross and net energy efficiency of the SOFC-GT hybrid system with cathode gas recirculation was much higher than that in the cycle without cathode recirculation at all $\Delta \mathrm{T}_{\text {cell, }}$, whereas, for the all $\Delta \mathrm{T}_{\text {cell, }}$, the energy input to the system was higher in the cycle with cathode exhaust gas recirculation.

- An increase in $\Delta \mathrm{T}_{\text {cell }}$ could increase gross exergy efficiency and net exergy efficiency of both hybrid system. The comparison of the system performance indicated that gross exergy and net exergy efficiency of the SOFC-GT hybrid system with cathode gas recirculation was much higher than that in the cycle without cathode recirculation at all $\Delta \mathrm{T}_{\text {cell, }}$, whereas, the exergy input to the system was higher in the cycle with cathode exhaust gas recirculation.

\section{References}

Aravind, P.V., Woudstra, T., Woudstra, N. \& Spliethoff, H. (2009) Thermodynamic evaluation of small scale systems with biomass gasifiers, solid oxide fuel cells with Ni/GDC anodes and gas turbines. J Power Sources, 190(2), 461-75.

Azami, V., \& Yari, M. (2017). Comparison between conventional design and cathode gas recirculation design of a direct- syngas solid oxide fuel cell-gas turbine hybrid systems part I: Design performance. International Journal of Renewable Energy Development, 6(2), 127-136.

Delft University of Technology. (2017) Cycle-tempo software (Release 5.0), http://www.asimptote.nl/software/cycle-tempo.

Delft University of Technology. (2017) Cycle-tempo manuals http://www.asimptote.nl/assets/media/7d155f62-ffe2-4a9e9f33-bb003c80bd2b.pdf

Fernandes, A., Woudstra, T. \& Aravind P. V. (2015) System simulation and exergy analysis on the use of biomassderived liquid-hydrogen for SOFC/GT powered aircraft. International Journal of Hydrogen Energy, 40: 4683-4697.

Ming, L., Aravind, P.V., Woudstra, T., Cobas, V.R.M. \& Verkooijena, A.H.M. (2011) Development of an integrated gasifier-solid oxide fuel cell test system: A detailed system study. J Power Sources, 196, 7277-89

Saebea, D., Patcharavochot, Y. \& Arpornwichanop, A. (2012) Analysis of an ethanolfuelled solid oxide fuel cell system using partial anode exhaust gas recirculation. $J$ Power Sources, 208, 120-30.

Saebea, D., Patcharavochot, Y. Assabumrungrat, S. \& Arpornwichanop, A. (2013) Analysis of a pressurized solid oxide fuel cellegas turbine hybrid power system with cathode gas recirculation. Int $J$ Hydrogen Energy, 38, 4748-59.

Santhanam, S., Schilt, C., Turker, B., Woudstra, T., \& Aravind P. V. (2016) Thermodynamic modeling and evaluation of high efficiency heat pipe integrated biomass Gasifier-Solid Oxide Fuel Cells-Gas Turbine systems. Energy, 109, 751764.

Thallam Thattai, A., Oldenbroek, V., Schoenmakers, L., Woudstra, T. \& Aravind P. V., (2017) Towards retrofitting integrated gasification combined cycle (IGCC) power plants with solid oxide fuel cells (SOFC) and $\mathrm{CO} 2$ capture - A thermodynamic case study. Applied Thermal Engineering, 114, 170-185.

Toonssen, R., Aravind, P.V., Smit, G., Woudstra, N. \& Verkooijen, A.H.M. (2010) System study on hydrothermal gasification combined with a hybrid solid oxide fuel cell gas turbine. Fuel Cells, doi:10.1002/fuce.2009001 